\title{
Cycloaddition Reaction of Ethyl Thioxoacetate and the Dienamine Derived from Pummerer's Ketone
}

\author{
Brahim Kouissa, ${ }^{1}$ Nourreddine Beghidja, ${ }^{2}$ Karim Bouchouit, ${ }^{1}$ and Mechehoud Youcef ${ }^{2}$ \\ ${ }^{1}$ Department of Chemistry, Faculty of Science, University of Jijel, Jijel 18000, Algeria \\ ${ }^{2}$ Department of Chemistry, Faculty of Science, University Mentouri Constantine, Constantine 25000, Algeria
}

Correspondence should be addressed to Nourreddine Beghidja; nourbeghidja@yahoo.fr

Received 15 March 2012; Revised 24 May 2012; Accepted 28 May 2012

Academic Editor: Ioannis Kourkoutas

Copyright (C) 2013 Brahim Kouissa et al. This is an open access article distributed under the Creative Commons Attribution License, which permits unrestricted use, distribution, and reproduction in any medium, provided the original work is properly cited.

The objective of this work is to study the regio- and stereochemistry of the cycloadducts obtained from the treatment of ethyl thioxoacetate and the dienamine derived from Pummerer's ketone.

\section{Introduction}

The use of Bunte salt (1), for example, the ethyl ester as precursors of thioaldehydes, for example, ethyl thioxoacetate, was described by the german chemist Hans Bunte [1,2]. This early work employed symmetrical dienes as trapping agents, the one exception being thebaine.

Kirby and coworkers [3-8] reported the formation of ethyl thioxoacetate (3) from sulphonyl chloride (2) by elimination of hydrogen chloride with triethylamine. The thioaldehyde was trapped by a variety of 1,3-dienes such as 2,3-dimethylbutadiene (4), cyclohexadiene(5), anthracene (6a), 9,10-anthracene (6b), and thebaine (7). The cycloadducts of the corresponding dienes (8), (9), (10), and (11) were obtained in high yields, as it is shown in Scheme 1.

The major thebaine cycloadduct (11) was found to be unstable. When it was heated under reflux in toluene for $8 \mathrm{~h}$, it was converted in high yield into the isomer (12) indicating that the cycloadduct (11) had been formed under kinetic control.

Y. Watanabe and T. Skakibara [9] treated 1,4-diacetoxy1,3-butadiene (13) with ethyl thioxoacetate (3) derived in situ from thioglycolate [10], and obtained an inseparable mixture of threo- and erythro-isomers in 68\% yield Scheme 2.

Recently, we reported [11] that treatment of the transient thioaldehyde (3) with unsymmetrical diene 1-methoxy-1,3cyclohexadiene (15) gave the cycloadducts (16) and (17) in good yield in an endo : exo ratio of $4: 1$, Scheme 3 .
The aim of the present study is to extend and explore the regiochemistry and stereochemistry of the reaction of ethyl thioxoacetate (3) with unsymmetrical diene, which is the dienamine (19) derived from Pummerer's ketone.

\section{Results and Discussion}

2.1. Cycloaddition Reaction of Ethyl Thioxoacetate and the Dienamine Derived from Pummerer's Ketone. With the aim of extending the study of thioxoacetate ester reactions with unsymmetrical conjugated dienes, a diene substituted in the $2-\mathrm{H}$ position with an amino group was selected. The compound chosen was the dienamine (19) prepared [12] from the readily accessible enone, Pummerer's ketone (18) (Scheme 4).

The dienamine was formed as oil, from the ketone and pyrrolidine in methanol, as described in reference [12], and used immediately without purification. The Bunte salt (1) was treated with triethylamine in ethanol-benzene in the presence of $1 \mathrm{~mol}$ equivalent of the dienamine (19) and calcium chloride dihydrate for 3 days. Then the mixture was workedup under acidic conditions, which could be hydrolysed to the enamine (20) to give the cycloadduct (21) as a gum in $20 \%$ yield (Scheme 5 ). The yield of this product was increased to $40 \%$ by using 3 mol equivalents of the Bunte salt (1) for 4 days. Purification of the adduct (21) was carried on preparative silica t. l. c. plates. 
TABLE 1: $200 \mathrm{MHz}^{1} \mathrm{H}$ N.M.R spectrum of the cycloadduct (21).

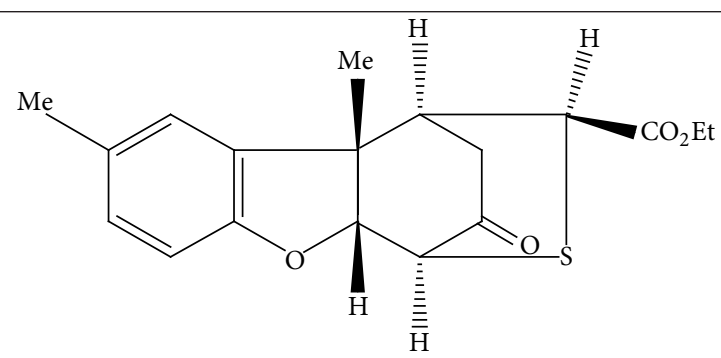

21

\begin{tabular}{lcc}
\hline Protons & $\delta$ P.P.m. & Coupling constants $(\mathrm{Hz})$ \\
\hline 7 & 6.93 & ddq, j8.2, 1.9 and 0.6 \\
9 & 6.86 & dP, $\mathrm{j} 1,9$ and 0.6 \\
6 & 6.61 & $\mathrm{dm}, \mathrm{j} 8.2$ and $<0.4$ \\
$4 \mathrm{a}$ & 4.86 & $\mathrm{dd}, \mathrm{j} 4.0$ and 0,7 \\
$\mathrm{OCH}{ }_{2} \mathrm{CH}_{3}$ & 4.21 & $\mathrm{q}, \mathrm{j} 7.2$ \\
$\mathrm{de} 11$ & 4.11 & $\mathrm{dd}, \mathrm{j} 2.9$ and 1.3 \\
4 & 3.35 & $\mathrm{~d}, \mathrm{j} 4.0$ \\
1 & 2.92 & $\mathrm{qd}, \mathrm{j} 3.1$ and 0.8 \\
$2 \beta$ & 2.57 & $\mathrm{dd}, \mathrm{j} 19.8$ and 3.1 \\
$8-\mathrm{Me}_{2 \alpha}$ & 2.26 & $\mathrm{~S}, \mathrm{with}$ fine splitting \\
$9 \mathrm{~b}-\mathrm{CH}_{3}$ & 1.97 & $\mathrm{ddd}, \mathrm{j} 19.8,3.3$ and 1.3 \\
$\mathrm{OCH}_{2} \mathrm{CH}_{3}$ & 1.63 & $\mathrm{~S}$ \\
\hline
\end{tabular}

TABLE 2: Nuclear overhauser difference $\mathrm{NOE}\left(\mathrm{CDCl}_{3} ; 200 \mathrm{MHz}\right)$ of the cycloadduct (21).

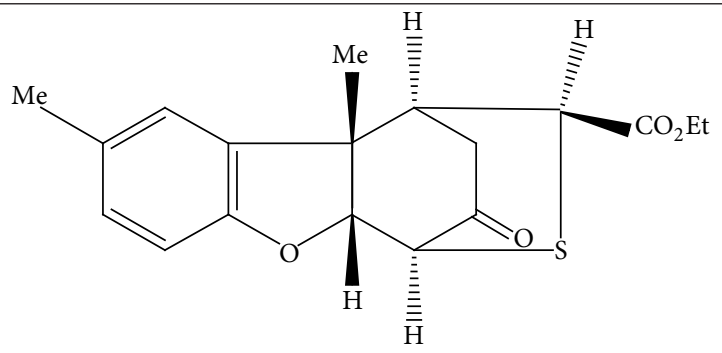

21

\begin{tabular}{lcccccccccccccc}
\hline $\begin{array}{l}\text { Irradiated } \\
\text { protons }\end{array}$ & $\delta$ & $1-\mathrm{H}$ & $2 \mathrm{~B}-\mathrm{H}$ & $2 \mathrm{~A}-\mathrm{H}$ & $4-\mathrm{H}$ & $4 \mathrm{a}-\mathrm{H}$ & $6-\mathrm{H}$ & $7-\mathrm{H}$ & $8-\mathrm{Me}$ & $9-\mathrm{H}$ & $9 \mathrm{~b}-\mathrm{Me}$ & $11-\mathrm{H}^{2}$ & $\mathrm{OCH}_{2} \mathrm{CH}_{3}$ & $\mathrm{OCH}_{2} \mathrm{CH}_{3}$ \\
\hline $1-\mathrm{H}$ & 2.92 & -74.75 & 2.06 & 1.62 & 0.09 & 0.17 & 0.14 & 0.53 & 0.03 & 4.54 & 1.47 & 4.78 & 0.64 & 0.45 \\
$2 \mathrm{~B}-\mathrm{H}$ & 2.57 & 2.72 & -56.59 & 21.16 & 0.26 & 0.26 & 0.32 & 0.23 & 0.31 & 0.67 & -0.3 & -0.03 & 0.24 & 0.13 \\
$2 \mathrm{~A}-\mathrm{H}$ & 1.97 & 1.99 & 20.95 & -62.44 & 0.26 & -0.01 & 0.16 & 0.09 & -0.71 & -0.13 & -0.15 & 0.29 & 0.51 & 0.29 \\
$4-\mathrm{H}$ & 3.35 & -0.03 & 0.08 & 0.26 & -65.22 & 6.1 & 0.08 & 0.07 & 0.07 & 0.08 & -0.12 & -0.06 & 0.17 & 0.12 \\
$4 \mathrm{a}-\mathrm{H}$ & 4.86 & 0.08 & 0.12 & 0.22 & 7.98 & -83.16 & 0.2 & 0.12 & 0.36 & 0.06 & 2.71 & 0.06 & 0.56 & 0.09 \\
$8-\mathrm{Me}$ & 2.26 & 0.01 & 0.09 & -0.52 & 0.09 & 0.38 & 0.21 & 7.02 & -262.8 & 6.98 & 0.1 & 0.06 & 0.16 & 0.32 \\
$9 \mathrm{~b}-\mathrm{Me}$ & 1.63 & 4.37 & 0.34 & 0.59 & -0.43 & 11.28 & 0.57 & 0.31 & 0.8 & 4.68 & -224.96 & 18.83 & 0.96 & 0.40 \\
$11-\mathrm{H}$ & 4.11 & 5.62 & -0.24 & 0.30 & 0.36 & 0.91 & 0.07 & -0.27 & 0.19 & 0.14 & 6.73 & -76.67 & -7.37 & 0.52 \\
$\mathrm{OCH}_{2} \mathrm{CH}_{3}$ & 4.21 & 0.40 & 0.17 & 0.35 & 0.13 & 0.26 & 0.09 & 0.22 & 0.30 & 0.05 & 0.57 & -6.58 & -150.13 & 4.98 \\
$\mathrm{OCH}_{2} \mathrm{CH}_{3}$ & 1.28 & 0.13 & 0.07 & 0.27 & 0.09 & 0.12 & 0.12 & 0.30 & 0.26 & 0.13 & 0.04 & 0.28 & 4.56 & -232.28 \\
\hline
\end{tabular}




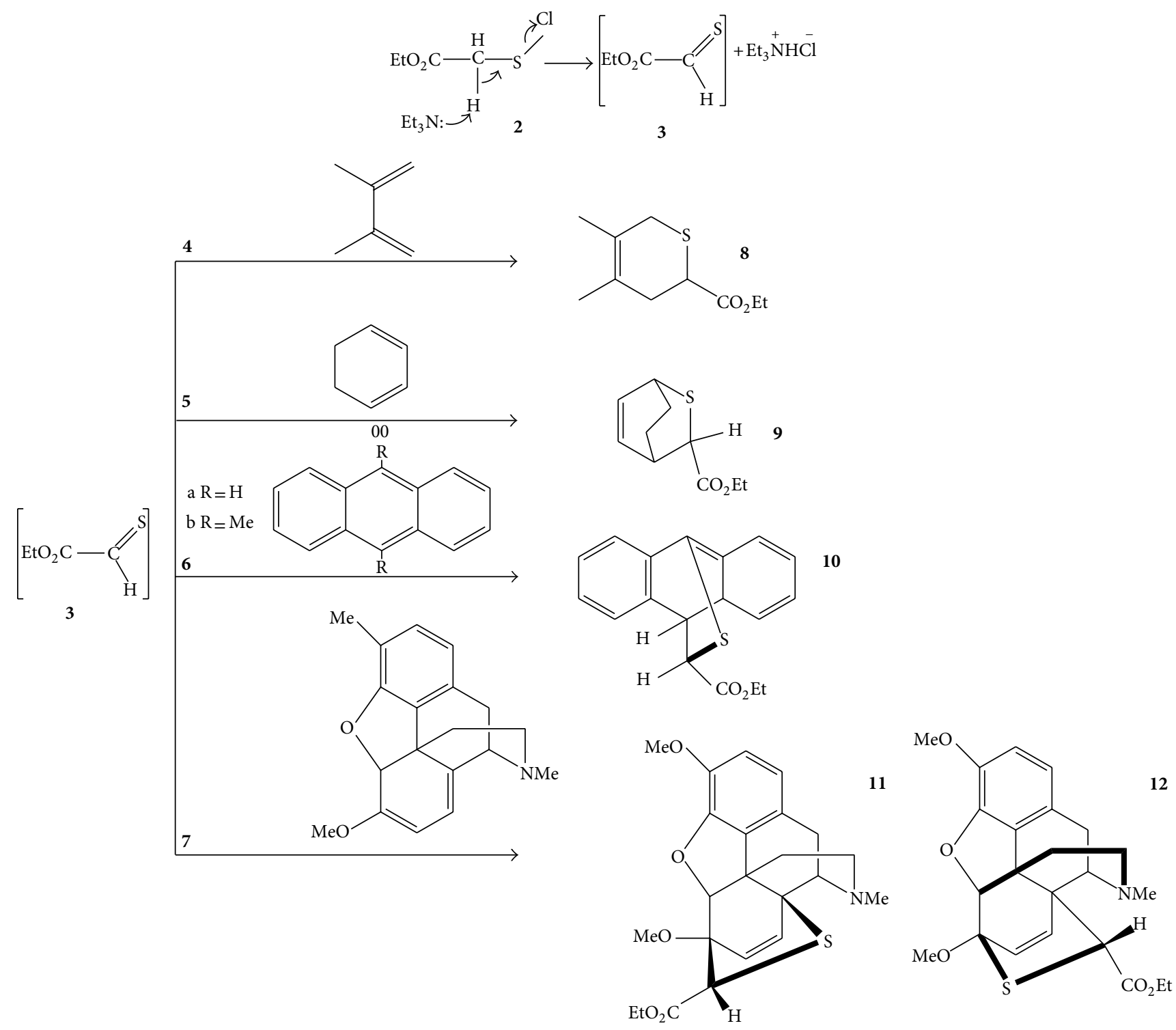

SCHEME 1

The molecular formula of the cycloadduct (5) was identified by accurate mass measurement. The fragmentation patterns are discussed in (Table 3). The presence of the carbonyl groups was confirmed by i. r. spectroscopy; a strong band at $\bar{\mu} 1730 \mathrm{~cm}^{-1}$ was attributed to both carbonyl groups. The structure of the adduct (21), with the exception of stereochemistry, was assigned on the basis of the ${ }^{1} \mathrm{H}$ n.m.r. spectrum. The $90 \mathrm{MHz}$ spectrum distinguishes between the 2 possible regioisomers (21) and (22) as shown in Scheme 6.

The 4a-H signal, $\delta 4,86(\mathrm{~d}, \mathrm{j} 4.0 \mathrm{~Hz})$, is easily recognized by its low field position, similar to that of the corresponding signal, $\delta 4,65$, in Pummerer's ketone (18), arising from deshielding by the inductive effect of oxygen. This allows identification of the signal for $4-\mathrm{H}, \delta 3.35(\mathrm{~d}, \mathrm{j} 4 \mathrm{~Hz})$, since no other signals have this splitting. The fact that this signal is a clean doublet discounts structure (22), since 4-H would be coupled with $11-\mathrm{H}$. It was not possible to established the stereochemistry (i.e., with of 4, racemic, diastereoisomers (21) is, assuming that the cis ring fusion of Pummerer's ketone is maintained) from the $90 \mathrm{MHz}$ spectrum (Scheme 7).

However, the $200 \mathrm{MHz}$ spectrum and the nuclear overhauser (n.o.e) studied (Tables 1 and 2) established the structure (21) unambiguously. The structure (21) can be distinguished from (21a) by the long-range "W" coupling, J $1.3 \mathrm{~Hz}$, between $\mathrm{H}-11$ and $2 \alpha-\mathrm{H}$. This coupling would not be expected in the isomer (21a). Importantly, this is supported by n.o.e experiments. Thus, irradiation at $\delta 4.11(11-\mathrm{H})$ increased the intensity of the singlet centered at $\delta 1.63$ (9b$\mathrm{Me})$. Conversely, the doublet at $\delta 4.11(11-\mathrm{H})$ increased in intensity when the methyl group, $\delta 1.63$ was irradiated. 


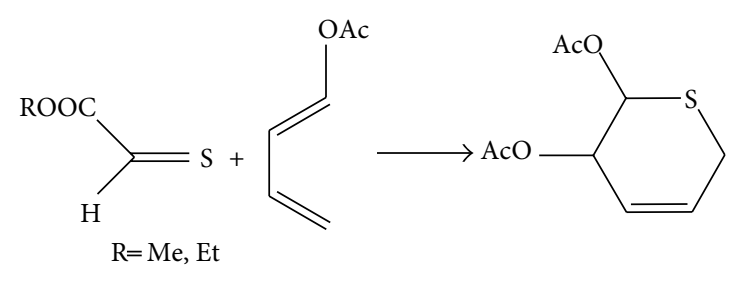

3

13

14

Scheme 2

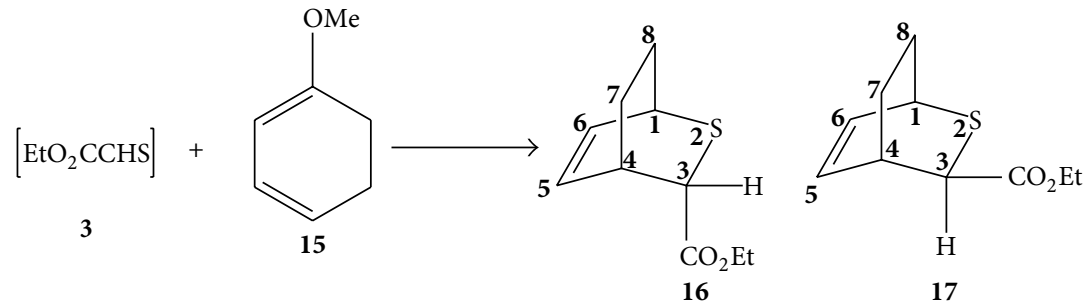

Scheme 3<smiles>Cc1ccc2c(c1)[C@]1(C)C=CC(=O)C[C@H]1O2</smiles>

18<smiles>Cc1ccc2c(c1)[C@]1(C)CCC(N3CCCC3)=C[C@H]1O2</smiles>

19

SCHEME 4

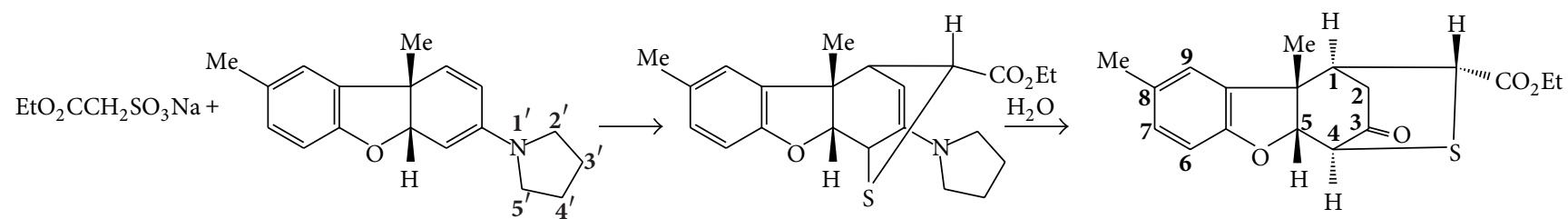
19
21

SCHeme 5

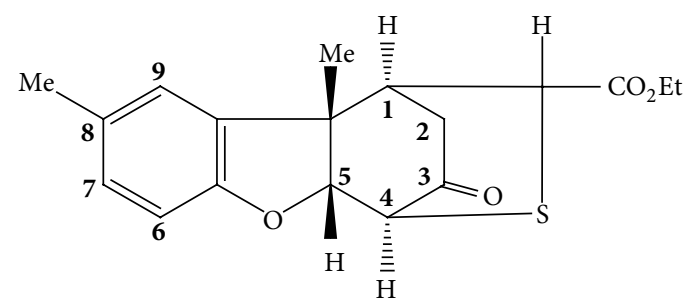

21<smiles>CCOC(=O)C1SC2CC(=O)C1[C@]2(C)c1cc(C)ccc1O</smiles>

22

SCHEMe 6 


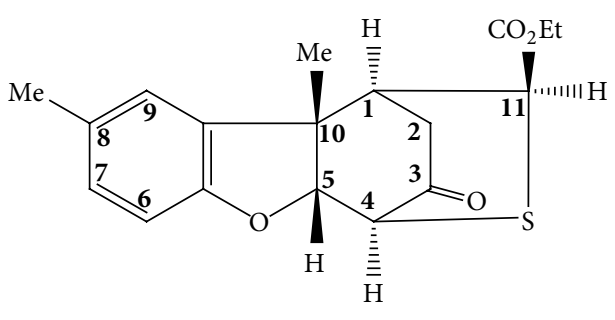

21a

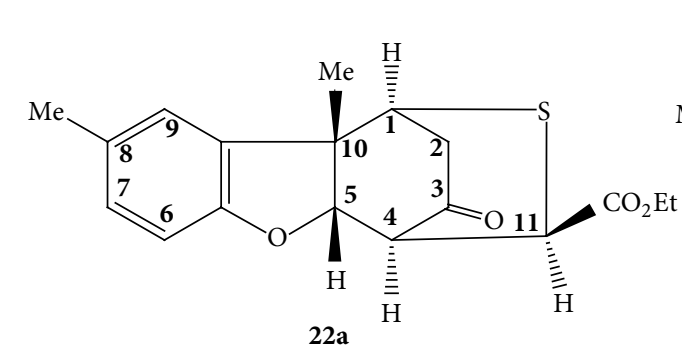

$22 \mathrm{a}$

SCHEME 7

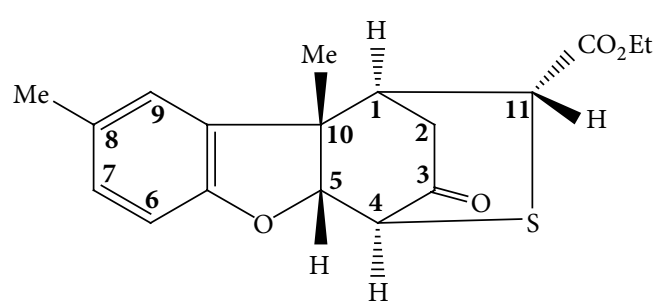

21

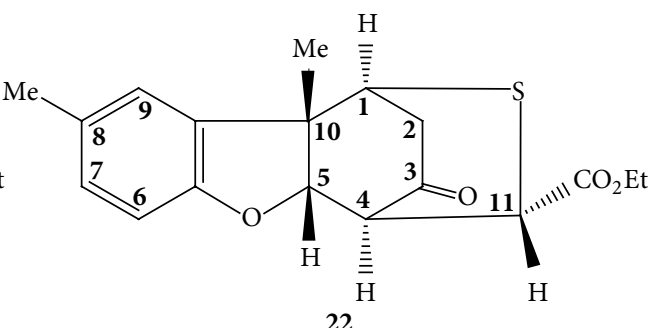

22

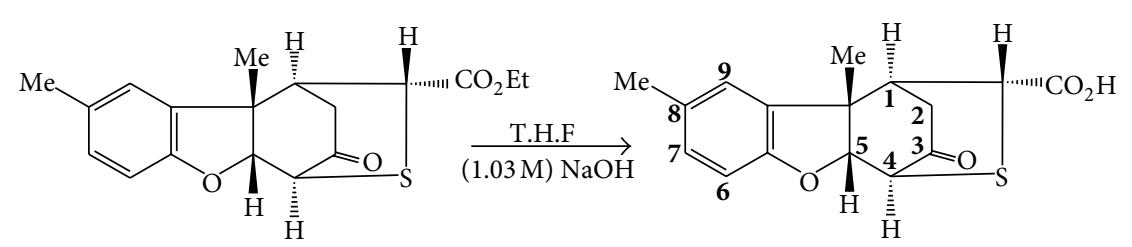

21

23

SCHEME 8

These observations establish the relative stereochemistry at the centers 11,1 , and $9 \mathrm{~b}$ and also confirm the regiochemistry.

When the cycloadduct (21) was hydrolysed with $1.03 \mathrm{M}$ sodium hydroxide in tetrahydrofuran at room temperature the acid (23) was obtained as a gum in $83 \%$ yield (Scheme 8).

The molecular formula, $\mathrm{C}_{16} \mathrm{H}_{16} \mathrm{O}_{4} \mathrm{~S}$, was determined by accurate mass measurementas shown in Table 4. The i. $\mathrm{r}$. spectrum showed a broad, strong band at $\bar{\mu} 1730 \mathrm{~cm}^{-1}$, arising from the ketonic and carboxylic carbonyl groups. The ${ }^{1} \mathrm{H}$ n.m.r. spectra of the ester (21) and the acid (23) were closely similar, apart from the replacement of ethoxyl signals by a broad hydroxyl signal, which disappeared upon exchange with deuterium oxide.

It was hoped that a crystalline product, suitable for combustion analysis, would be obtained. However, so far the acid (23) has resisted crystallization.

The formation of predominantly only one (21) of eight possible diastereoisomers requires comment. Vedejs et al. reported [13] a related cycloaddition reaction. They found that the thioaldehydes having electron-withdrawing groups (ZCHS; $\mathrm{Z}=\mathrm{CN}, \mathrm{CO}_{2} \mathrm{CH}_{3}$, or $\mathrm{COCH}_{3}$ ), generated from the phenacyl sulphides, could be trapped by 2 -ethoxybutadiene to give Diels-Alder adducts. The compounds with sulphur attached to $\mathrm{C}$ (1) of the diene were found to be formed predominantly. This regiochemistry corresponds to that observed in the reaction of thioxoacetate and the dienamine (19). The unusually high endo selectivity of the latter reaction could be due to the strong steric repulsion between the 9bmethyl and ester groups in the exo isomer. Finally, attack by the thioaldehyde on the dienamine (19) has occurred cis to the 9b-methyl group and 4a-hydrogen atom and trans to the larger 9b-aryl group and 4a-oxygen atom. The $200 \mathrm{MHz}$ ${ }^{1} \mathrm{H}$ n.m.r spectrum showed weak signals that could represent another isomer, but otherwise the reaction was remarkably stereo- and region-selective.

\section{Experimental}

3.1. Preparation of 1-(4a,9b-Dihydro-8-9b-dimethyl-3-dibenzofuranyl)Pyrrolidine (19). Following the steps developed in reference [12], pyrrolidine $(0.85 \mathrm{~mL})$ was added to a suspension of $4 \mathrm{a}, 9 \mathrm{~b}$-dihydro-8,9b-dimethyl-dibenzo-furan-3(4H)one, Pummerer's ketone (18) $(0.5 \mathrm{~g}, 2.3 \mathrm{mmol})$ in methanol $(12.5 \mathrm{~mL})$, and the mixture was heated in a steam bath for $10 \mathrm{~min}$. The resulting clear yellow solution was allowed to stand at room temperature for $1 \mathrm{~h}$. After that, evaporated from the solution which resulted in a yellow syrupy residue which was redissolved in benzene and evaporated to dryness to yield the dienamine (19) $(0.61 \mathrm{~g}, 98 \%)$ as a yellow syrupy. Found: m/z 267 (M, basepeak); ( $\left.\bar{\mu} \mathrm{CHCl}_{3}\right) 1580$ (weak band) 
TABLE 3: Mass spectrum of Ethyl 1,2,3,4a,9b-hexahydro-8,9b-dimethyl-3-oxo-4,1-(epithiomethano)dibenzofuran-11-endo-carboxylate (21).

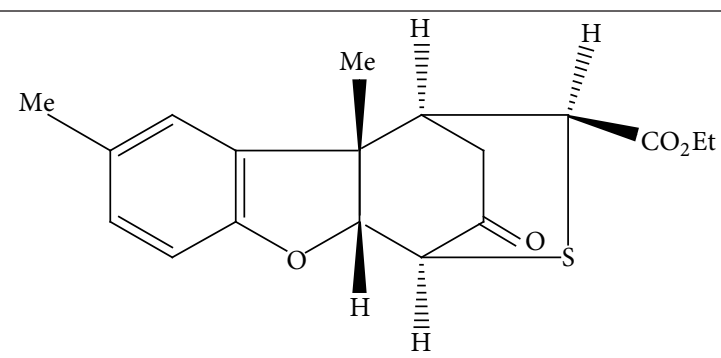

21

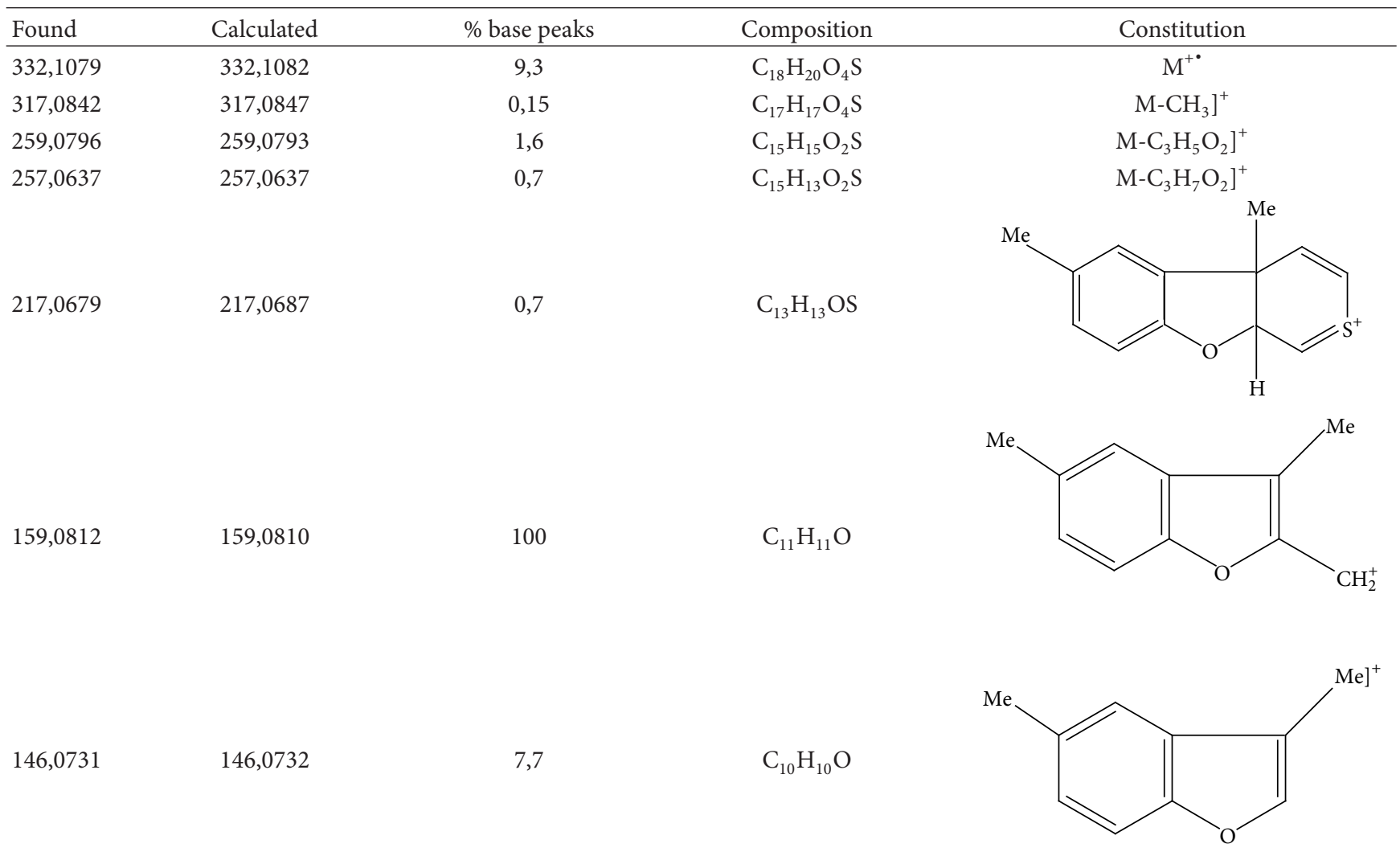

and $1650 \mathrm{~cm}^{-1}$ (strong band); $\delta\left(\mathrm{CDCl}_{3}, 90 \mathrm{MHz}\right) 1.36(\mathrm{~S}, 9 \mathrm{~b}-$ $\left.\mathrm{CH}_{3}\right), 1.85\left(\mathrm{~m}, 3^{\prime}\right.$ - and $\left.4^{\prime}-\mathrm{CH}_{2}\right), 2.25\left(\mathrm{~S}, 8-\mathrm{CH}_{3}\right), 3.2\left(\mathrm{~m}, 2^{\prime}-\right.$ and $\left.5^{\prime}-\mathrm{CH}_{2}\right), 4.5-6.5$ (bs, $\left.4 \mathrm{H}\right)$, and 6.55-7.2 (m, aryl-H).

\subsection{Preparation of the Cycloadduct 21 of Ethyl Thioxoacetate} and 1-(4a,9b-Dihydro-8-9b-dimethyl-3-dibenzofuranyl) Pyrrolidine (19). The Bunte salt (3) $(0.478 \mathrm{~g}, 2.05 \mathrm{mmol})$ and calcium chloride dihydrate $(0.32 \mathrm{~g}, 2.05 \mathrm{mmol})$ were dissolved in ethanol (15 mL). Then dienamine (19) $(0.457 \mathrm{~g}$, $1.72 \mathrm{mmol})$ in benzene $(15 \mathrm{~mL})$ and triethyl-amine $(0.218 \mathrm{~g}$, $2.05 \mathrm{mmol}$ ) were added to the mixture of salts. The reaction mixture was stirred at room temperature for 3 days then was diluted with analar chloroform $(40 \mathrm{~mL})$ and water $(30 \mathrm{~mL})$. After that dilute $(5 \%)$ hydrochloric acid was added until the calcium sulphite had dissolved and the mixture had become clear. The organic layer was washed successively with aqueous sodium hydrogen carbonate, brine $(10 \mathrm{~mL})$, and water $(20 \mathrm{~mL})$, subsequently dried over $\left(\mathrm{MgSO}_{4}\right)$, and evaporated. The obtained residue $(0.55 \mathrm{~g})$ was chromatographed on a silica $\left(\mathrm{HF}_{254}\right)$ column. Elution with light petroleum-chloroform $(1: 1)$ gave a mixture $(0.37 \mathrm{~g})$ which was separated on silica t. 1 . c. plates developed several times with light petroleum-ether $(7: 3)$, to give ethy1 1,2,3,4a,9b-hexahydro-8,9b-dimethyl-3-oxo-4,1(epithiomethano)dibenzofuran-11-endo-carboxylate (21) (100 mg, 18\%). (Found: $\mathrm{m} / \mathrm{z} 332.1079 ; \mathrm{C}_{18} \mathrm{H}_{20} \mathrm{O}_{4} \mathrm{~S}$ requires $\mathrm{M}, 332.1077 ; \bar{\mu}\left(\mathrm{CHCl}_{3}\right)$ (strong band) $1730 \mathrm{~cm}^{-1}, \delta\left(\mathrm{CDCl}_{3}\right.$, $90 \mathrm{MHz}) 1.28\left(\mathrm{t}, \mathrm{J} 7.0 \mathrm{~Hz}, \mathrm{OCH}_{2} \mathrm{CH}_{3}\right), 1.67\left(\mathrm{~S}, 9 \mathrm{~b}-\mathrm{CH}_{3}\right)$ $2.26\left(\mathrm{~S}, 8-\mathrm{CH}_{3}\right), 1.97-2.57\left(\mathrm{~m}, 2-\mathrm{CH}_{2}\right), 2.92(\mathrm{~m}, 1-\mathrm{H}), 3.35$ (d, J4.0 Hz, 4-H), $4.11(\mathrm{~m}, 11-\mathrm{H}), 4.21$ (q, J7 Hz), 4.86 (d, $\mathrm{J} 4.0 \mathrm{~Hz}, 4 \mathrm{a}-\mathrm{H})$, and 6.60-6.95 (m, 6-, 7-, and 9- $\mathrm{H}) ; \delta\left(\mathrm{CDCl}_{3}\right.$; $200 \mathrm{MHz}) 1.28\left(\mathrm{t}, \mathrm{J} 7.2 \mathrm{~Hz}, \mathrm{OCH}_{2} \mathrm{CH}_{3}\right), 1.63\left(\mathrm{~S}, 9 \mathrm{~b}-\mathrm{CH}_{3}\right)$, 1.97 (ddd, J19.8, 3, 3, and $1.3 \mathrm{~Hz}, 2 \alpha-\mathrm{H}$ ), 2.26 (S with fine splitting, 8- $\mathrm{CH}_{3}$ ), 2.57 (dd, J19.8 and $3.1 \mathrm{~Hz}, 2 \beta-\mathrm{H}$ ), 2.92 (qd, J3.1 and $0.8 \mathrm{~Hz}, 1-\mathrm{H}$ ), 3.35 (d, J4.0 Hz, 4-H), 4.11 (dd, 
TABle 4: Mass spectrum of 1,2,3,4a,9b-hexahydro-8,9b-dimethyl-3-oxo-4,1-(epithiomethano)dibenzofuran-11-endo-carboxylic acid (23).

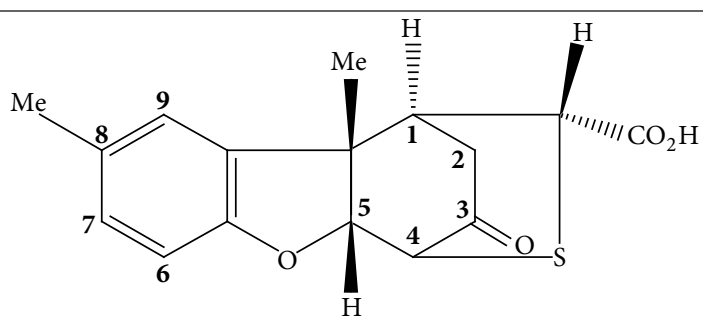

23

\begin{tabular}{|c|c|c|c|c|}
\hline Found & Calculated & $\%$ & Composition & Constitution \\
\hline 304.0773 & 304.0769 & 7.6 & $\mathrm{C}_{16} \mathrm{H}_{16} \mathrm{O}_{4} \mathrm{~S}$ & $\mathrm{M}^{+\bullet}$ \\
\hline 215.0511 & 215.0521 & 0.7 & $\mathrm{C}_{13} \mathrm{H}_{11} \mathrm{OS}$ & $\left.\mathrm{M}-\mathrm{C}_{3} \mathrm{H}_{5} \mathrm{O}_{3}\right]^{+\bullet}$ \\
\hline 214.0993 & 214.0994 & 2.1 & $\mathrm{C}_{14} \mathrm{H}_{14} \mathrm{O}_{2}$ & \\
\hline 159.0809 & 159.0810 & 100 & $\mathrm{C}_{11} \mathrm{H}_{11} \mathrm{O}$ & \\
\hline 146.0727 & 146.0731 & 11.3 & $\mathrm{C}_{10} \mathrm{H}_{10} \mathrm{O}$ & \\
\hline
\end{tabular}

J2.9 and $1.3 \mathrm{~Hz}, 11-\mathrm{H}), 4.21\left(\mathrm{q}, \mathrm{J} 7.2 \mathrm{~Hz}, \mathrm{OCH}_{2} \mathrm{CH}_{3}\right), 4.86$ (dd, J4.0 and $0.7 \mathrm{~Hz}, 4 \mathrm{a}-\mathrm{H}) 6.61(\mathrm{dm}, \mathrm{J} 8.2$ and $0.4 \mathrm{~Hz}, 6-\mathrm{H})$, $6.86(\mathrm{dp}, \mathrm{J} 1.9$ and $0.6 \mathrm{~Hz}, 9-\mathrm{H})$, and $6.93(\mathrm{ddq}, \mathrm{J} 8.2,1.9$ and $0.6 \mathrm{~Hz}, 7-\mathrm{H})$.

3.3. Preparation of the Cycloadduct Ketone 21 Using $3 \mathrm{~mol}$ Equivalents of the Bunte Salt. The Bunte salt (3) (0.743 g, $3.35 \mathrm{mmol}$ ) and calcium chloride dihydrate $(0.493 \mathrm{~g}$, $3.35 \mathrm{mmol})$ were dissolved in ethanol $(15 \mathrm{~mL})$. A mixture of the dienamine (19) $(0.299 \mathrm{~g}, 1.12 \mathrm{mmol})$ and triethylamine $(0.339 \mathrm{~g}, 3.35 \mathrm{mmol})$ was added to the salt mixture. The reaction mixture was stirred at room temperature for 4 days then was worked up and chromatographed as described before to give the ketone (21) $(0.12 \mathrm{~g}, 33.4 \%)$. The ${ }^{1} \mathrm{H}$ n.m.r. spectrum was identical obtained by using $1 \mathrm{~mol}$ equivalent of the Bunte salt.

3.4. Hydrolysis of the Ester 21. 1.03 M sodium hydroxide $(1 \mathrm{~mL})$ was added to a solution of the ester (21) (40 mg, $0.12 \mathrm{mmol})$ in tetrahydrofuran $(2 \mathrm{~mL})$ and the mixture was stirred at room temperature overnight. After $24 \mathrm{~h}$ the solution was concentrated with slight heating under reduced pressure. The resulting aqueous solution was concentrated, washed with ether $(5 \times 10 \mathrm{~mL})$, then acidified with $5 \%$ hydrochloric acid $(2 \mathrm{~mL})$ and after extracted with ether $(5 \times 10 \mathrm{~mL})$. The ethereal extracts were washed with brine $(5 \mathrm{~mL})$, dried $\left(\mathrm{MgSO}_{4}\right)$, and evaporated under reduced pressure with slight heating to give the acid (23) (30 mg, 83\%) as an amorphous solid. (Found: $\mathrm{m} / \mathrm{z} 304.0773 ; \mathrm{C}_{16} \mathrm{H}_{16} \mathrm{O}_{4} \mathrm{~S}$ requires $\mathrm{M}$, 304.0765): $\bar{\mu}\left(\mathrm{CHCl}_{3}\right) 1730 \mathrm{~cm}^{-1}$ (strong band); $\delta\left(\mathrm{CDCl}_{3}\right.$, $90 \mathrm{MHz}) 1.65\left(\mathrm{~s}, 9 \mathrm{~b}-\mathrm{CH}_{3}\right), 2.26\left(\mathrm{~s}, 8-\mathrm{CH}_{3}\right), 1.80-2.90(\mathrm{~m}, 2-$ $\mathrm{CH}_{2}$ ), 2.95 (m, 1-H), 3.40 (d, J $\left.4.0 \mathrm{~Hz}, 4-\mathrm{H}\right), 4.19$ (m, 11-H), 4.87 (d, J 4.0 Hz, 4a-H), 6.57-7.0 (m, 6-, 7- and 9-H), and 8.0 (bs, $\mathrm{COOH}$ ).

\section{References}

[1] G. W. Kirby, A. W. Lochead, and G. N. Sheldrake, "Generation of thioaldehydes from sodium thiosulphate S-esters (bunte salts)," Journal of the Chemical Society, Chemical Communications, no. 14, pp. 922-923, 1984.

[2] H. Bunte, Chemische Berichte, vol. 7, p. 646, 1974. 
[3] C. M. Bladon, G. W. Kirby, A. W. Lochead, and D.C. Mc Dougal, Journal of the Chemical Society, Chemical Communications, vol. 423, 1984.

[4] R. I. Gourly and J. W. Kirby, Journal of Chemical Research, pp. 1001-1020, 1997.

[5] C. F. Henderson, G. W. Kirby, and J. Edmiston, "Synthesis from thebaine of 10 -oxothebaine, potentially a precursor for $\kappa$ selective opiates opioids," Journal of the Chemical Society, Perkin Transactions, vol. 1, pp. 295-297, 1994.

[6] M. D. Aceto, L. S. Harris, M. E. Abood, and K. C. Rice, "Stereoselective $\mu$ - and $\delta$-opioid receptor-related antinociception and binding with (+)-thebaine," European Journal of Pharmacology, vol. 356, no. 2-3, pp. 143-147, 1985.

[7] C. M. Bladon, G. W. Kirby, A. W. Lochead, and D. C. McDougal, Journal of the Chemical Society, Perkin Transactions, vol. 15, 1985.

[8] R. I. Gourlay and J. W. Kirby, "Short synthesis of $14 \beta$ acylaminocodeinones from the cycloadducts of thebaine and acylnitroso compounds," Journal of Chemical Research, no. 5, pp. 152-153, 1997.

[9] Y. Watanabe and T. Skakibara, "Synthesis of methyl 4,6-O-benzylidene-2,3-dideoxy-5-thio- $\beta$-dl-threo-hex-2enopyranoside via hetero-Diels-Alder reaction and unusual stabilities of 1,5-anhydro-4,6-O-benzylidene 2,3-dideoxy-5thio-dl-threo-hex-2-enitol," Tetrahedron, vol. 65, no. 3, pp. 599-606, 2009.

[10] D. Adam, A. A. Freer, N. W. Isaacs, G. W. Kirby, A. Littlejohn, and M. S. Rahman, "Synthesis of a thiashikimic acid derivative," Journal of the Chemical Society, Perkin Transactions, vol. 1, no. 10, pp. 1261-1264, 1992.

[11] B. Kouissa, M. Belghobsi, N. Beghidja, and A. Bouchoul, "Cycloaddition of ethyl thioxoacetate and 1-methoxy-1,3cyclohexadiene," Research Journal of Pharmaceutical, Biological and Chemical Sciences, vol. 2, no. 1, pp. 727-736, 2011.

[12] E. B. Marlock, J. D. Albright, and L. Goldman, U.B.P, vol. 3, pp. 646-660, 1972.

[13] E. Vedejs, T. H. Eberlin, and D. L. Varie, "Dienophilic thioaldehydes," Journal of the American Chemical Society, vol. 104, no. 5, pp. 1445-1447, 1982. 

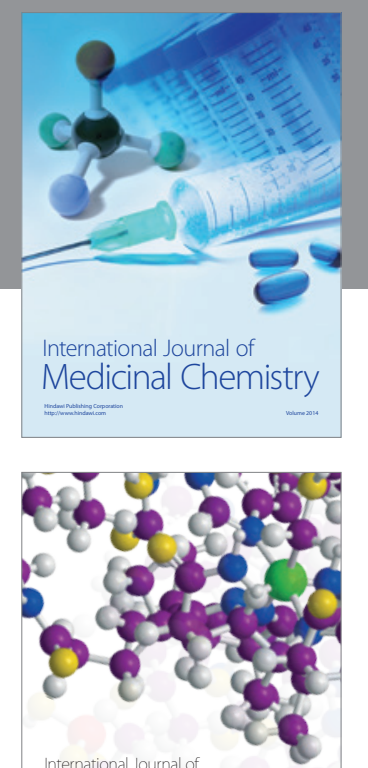

\section{Carbohydrate} Chemistry

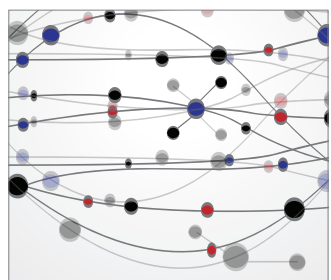

The Scientific World Journal
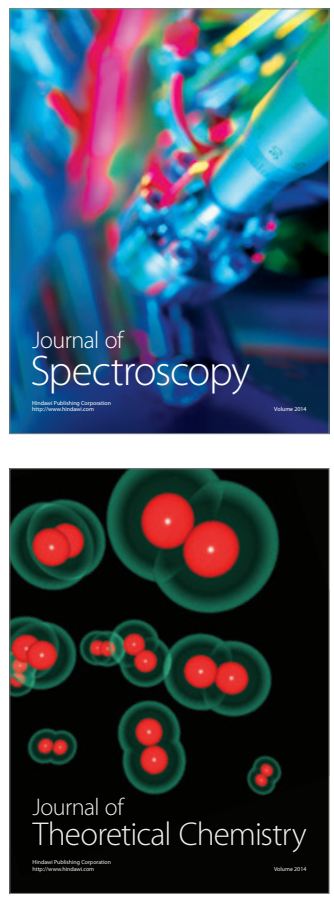
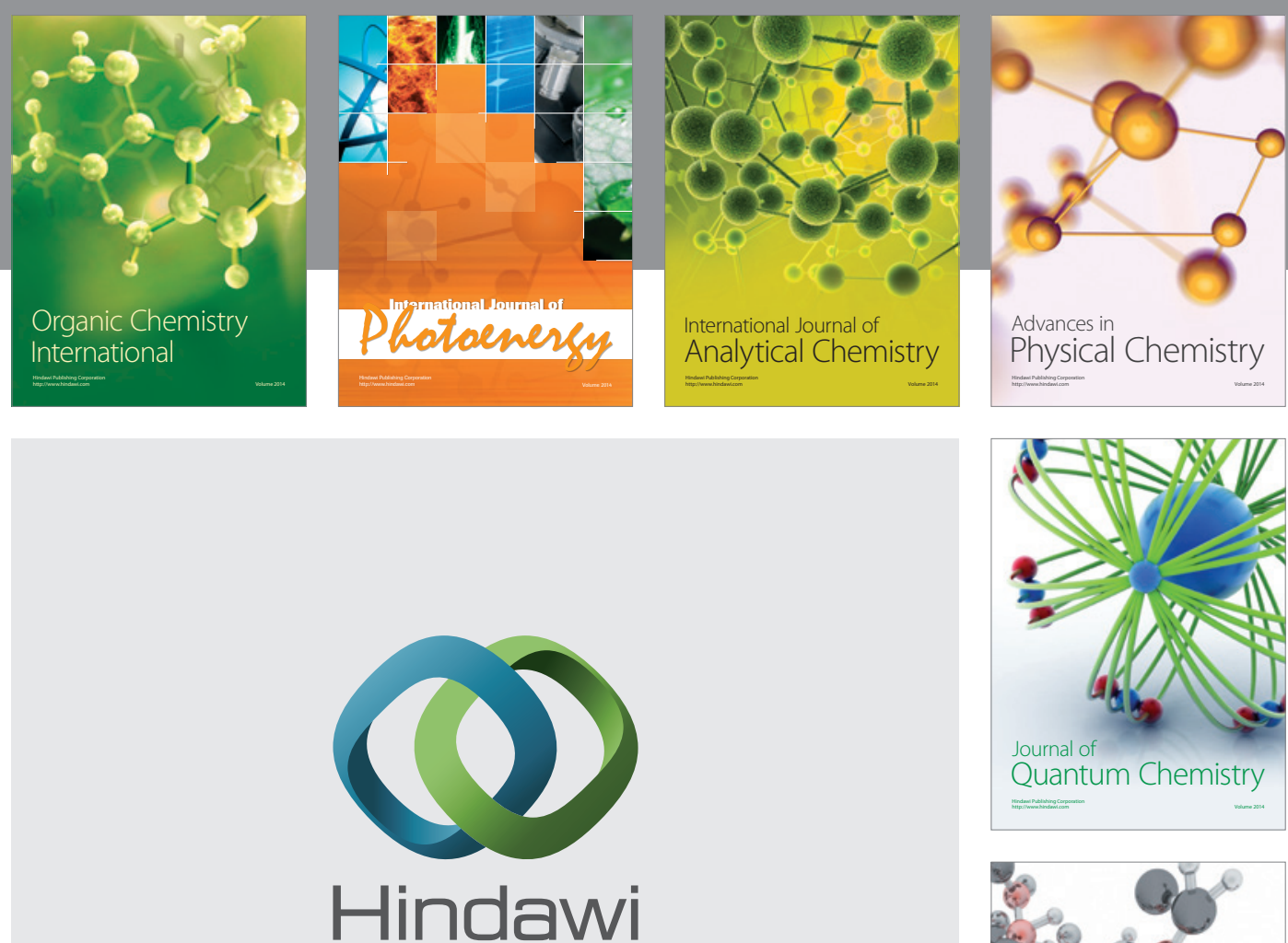

Submit your manuscripts at

http://www.hindawi.com

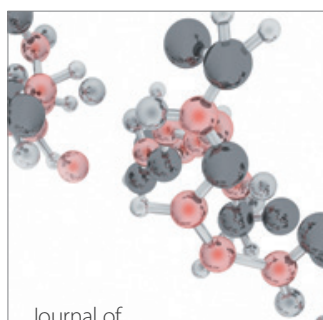

Analytical Methods

in Chemistry

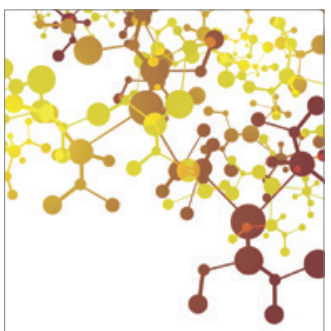

Journal of

Applied Chemistry

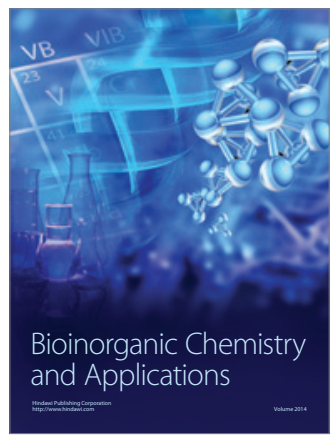

Inorganic Chemistry
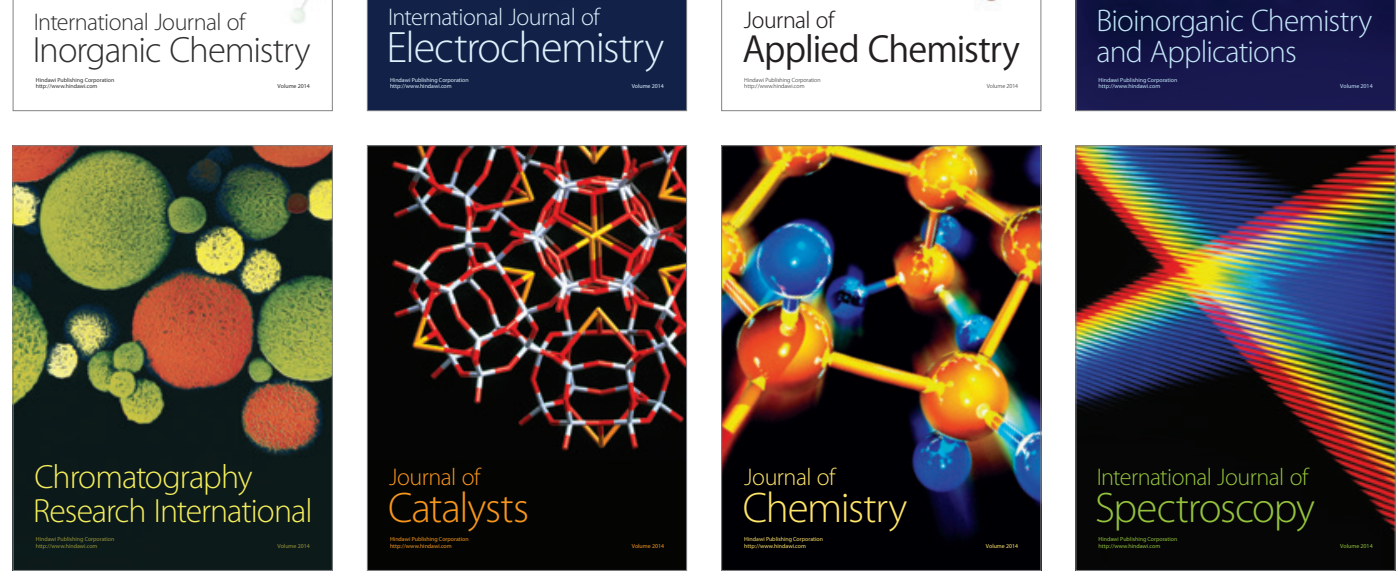